\title{
Irrigation water for vegetation establishment
}

\author{
R.E. RIES, F.M. SANDOVAL, AND J.F. POWER
}

\section{Abstract}

This research project was conducted to evaluate the use of irrigation water to supplement precipitation during establishment of perennial forage plant communities on surface mined lands in the northern Great Plains. The treatments included precipitation and 9 combinations of various quantities of medium and low quality water applied to a clay loam topsoil replaced over a loam minespoil. We measured the response to the added water of a seeded forage species mixture, volunteer weeds, and changes in salinity and sodicity of the soil/spoil profile. All levels of irrigation, regardless of water quality, increased seeded species production, but decreased weed dry matter. One season of irrigation with medium or low quality water produced minimal changes in soil salinity and sodicity. Some increase in soil sallnity and sodicity was observed when low quality water was added during the second season. Therefore, low quality water can be used beneficially to supplement precipitation for 1 or 2 seasons during the establishment of perennial plant communities on moderately permeable soil/spoil areas.

Key Words: irrigation, grass/legume, sodicity, salinity, revegetation, reclamation, perennial forages

Prompt reestablishment of vegetation on disturbed lands is important to protect replaced soil materials from excessive soil erosion. Successful revegetation in the semiarid and arid West (Ries and Day 1978) is dependent on amount and distribution of precipitation. Irrigation to supplement natural precipitation during stand establishment of perennial plant communities is often beneficial, especially when precipitation is limited (Ries 1980).

Within the lignite fields of North Dakota, most ground waters (Croft 1974) and surface impounded waters (Gilley et al. 1976) are of marginal quality for irrigation. Because these waters usually have to be disposed of during mining, there has been interest in using them for irrigation during perennial plant community establishment. Recent studies have shown the usability of poor quality water, even sea water, for crop production with carefully managed irrigation practices (Epstein and Norlyn 1977, Thomas et al. 1981). Other research using blowdown water (a highly saline water resulting from power plant cooling towers) has shown similar usability (Zartman et al. 1980, Jury et al. 1980).

The research reported in this paper was conducted to evaluate

\footnotetext{
Authors are range scientist and soil scientists, respectively, USDA-ARS, Northern Great Plains Research Laboratory, P.O. Box 459, Mandan, ND 58554. J.F. Power is now with the USDA-ARS, Soil and Water Conservation Research Unit, University of Nebraska, Lincoln 68583. F.M. Sandoval, retired, 4685 Clearview Rd., Belgrade, Mont. 59714.

The authors wish to thank Knife River Coal Mining Company and their personnel for help throughout this study.

Manuscript accepted 21 December 1987.
}

the use of marginal quality water to supplement precipitation during establishment of perennial forage plant communities on surface mined lands. Results could also be applied to grass establishment on undisturbed lands.

\section{Study Area and Methods}

This research was conducted in southwestern North Dakota, near Gascoyne about $46^{\circ} \mathrm{N}, 103^{\circ} \mathrm{W}$, on land that had been surface mined for lignite. Soil in the area before mining was Shambo loam (fine-loamy, mixed Typic Haploboroll) on nearly level to gentle slopes. Climate is continental, with frequent and rapid temperature changes throughout the year. Average annual temperature is $6.1^{\circ}$ $C$ and the highly variable precipitation averages $380 \mathrm{~mm}$ annually. Seventy percent of the long-term average precipitation falls from May through September with June being the wettest month (almost $100 \mathrm{~mm}$ ). Droughts are common and may last for months or years. Potential evapotranspiration is about twice average precipitation.

After mining, mine spoils were leveled to less than $1 \%$ grade, disked, and an average thickness of $210 \mathrm{~mm}$ of topsoil spread over the plot area. The plot area was fertilized with $18 \mathrm{~kg} \mathrm{~N}$ and $35 \mathrm{~kg}$ $P /$ ha, disked and harrowed. A total of 30 plots, 120 by $180 \mathrm{~cm}$, were established on the plot area in 3 blocks.

Soil and spoil samples were taken from each plot in June of 1977 , prior to seeding, to characterize soil and spoil on the plot area Topsoil was sampled in depth increments of 0 to 100 to $210 \mathrm{~mm}$ Spoil was sampled in $150-\mathrm{mm}$ increments from 210 through 810 $\mathrm{mm}$, and in $300-\mathrm{mm}$ increments from 810 to $1,710 \mathrm{~mm}$. Each sample was composed of 2 separate cores, $36 \mathrm{~mm}$ diameter, composited by depth increment. Laboratory procedures are described in Handbook 60 (USDA 1954) and Handbook 525 (Sandoval and Power 1977). The soil and spoil pH was determined on a saturation paste and electrical conductivity (EC) on paste extract. Atomic absorption spectrophotometry was used to determine calcium, magnesium, and sodium concentrations in the saturation extract. Sodium adsorption ratio (SAR) was calculated for each soil and spoil sample to evaluate sodicity. Texture (\% sand, silt and clay) was determined by the hydrometer method. The same procedures for sampling and analysis of the soil and spoil were repeated each fall after harvest in 1977, 1978, and 1979.

Calcium carbonate and gypsum concentrations were determined because some acid $\mathrm{pH}$ values were encountered in lower depths of the spoil. The low $\mathrm{pH}$ was probably caused by an excess of hydrogen ions from the lignite contained in the spoil materials. However, low $\mathrm{pH}$ should be a transitory condition because of the high levels of calcium reserve in these materials. Soil and spoil characteristics on the research plots at the start of the study are given in Table 1. 
Each plot was broadcast seeded June 30, 1977, at a rate of 13.4 $\mathrm{kg} /$ ha pure live seed (pls) of a grass-legume mixture [23\% western wheatgrass (Agropyron smithii Rydb.); $11 \%$ slender wheatgrass [A. trachycaulum (Link) Malte.]; 17\% green needlegrass (Stipa viridula Trin.); $42 \%$ annual rye (Secale cereale L.); and $7 \%$ yellow sweetclover (Melilotus officinalis (L.) Lam.)]. The plots were raked by hand to cover the seed.
Precipitation was measured on site during each growing season with a standard recording rain gauge. Pan evaporation, air temperatures, and wind speed were measured with standard U.S. Weather Bureau equipment (Table 2 and 3).

Medium and low quality waters were used in this study to supplement precipitation. The medium quality water came from the Missouri River and a well near the Gascoyne mine. The low

Table 1. Soil and spoil characteristics.

\begin{tabular}{|c|c|c|c|c|c|c|c|c|c|}
\hline Depth & pH & $\begin{array}{l}\mathrm{CaCO} 3 \\
\text { Equiv. }\end{array}$ & Gypsum & Sand & Silt & Clay & Texture! & $\mathrm{EC}^{2}$ & $\mathbf{S A R}^{3}$ \\
\hline $\begin{array}{l}\text { (mm) } \\
\text { Topsoil }\end{array}$ & & & $\mathrm{M} \mathrm{mol} / \mathrm{kg}^{-1}$ & - - - & $-\%-$ & - & & $\mathrm{dS} \mathrm{m}^{-1}$ & \\
\hline $\begin{array}{l}0-100 \\
100-210\end{array}$ & $\begin{array}{l}7.4^{4} \\
7.4\end{array}$ & $\begin{array}{l}8.3 \\
7.8\end{array}$ & $\begin{array}{l}0.8 \\
0.5\end{array}$ & $\begin{array}{l}36 \\
36\end{array}$ & $\begin{array}{l}36 \\
36\end{array}$ & $\begin{array}{l}28 \\
28\end{array}$ & $\begin{array}{l}\text { CL } \\
\text { CL }\end{array}$ & $\begin{array}{l}4.9 \\
5.5\end{array}$ & $\begin{array}{l}5.5 \\
7.2\end{array}$ \\
\hline $\begin{array}{l}\text { Spoil } \\
210-360 \\
360-510 \\
510-660 \\
660-810 \\
810-1110 \\
1110-1410 \\
1410-1710\end{array}$ & $\begin{array}{l}6.3 \\
6.1 \\
6.0 \\
5.9 \\
5.8 \\
5.9 \\
5.6\end{array}$ & $\begin{array}{l}4.2 \\
2.9 \\
2.4 \\
2.5 \\
2.8 \\
3.0 \\
2.4\end{array}$ & $\begin{array}{l}2.7 \\
3.3 \\
3.7 \\
3.6 \\
2.6 \\
2.8 \\
2.3\end{array}$ & $\begin{array}{l}35 \\
35 \\
35 \\
36 \\
36 \\
39 \\
39\end{array}$ & $\begin{array}{l}41 \\
41 \\
41 \\
41 \\
41 \\
40 \\
40\end{array}$ & $\begin{array}{l}24 \\
24 \\
24 \\
23 \\
23 \\
21 \\
21\end{array}$ & $\begin{array}{l}\text { L } \\
\text { L } \\
\text { L } \\
\text { L } \\
\text { L } \\
\text { L } \\
\text { L }\end{array}$ & $\begin{array}{l}6.2 \\
5.7 \\
5.7 \\
5.7 \\
5.8 \\
5.9 \\
5.4\end{array}$ & $\begin{array}{l}4.5 \\
3.6 \\
3.6 \\
3.6 \\
3.7 \\
3.7 \\
3.5\end{array}$ \\
\hline
\end{tabular}

${ }^{1} \mathrm{CL}$, clay loam; $\mathrm{L}$, loam.

2Salinity as measured by electrical conductivity (EC).

${ }^{3}$ Sodium adsorption ration $=\mathrm{SAR}=\mathrm{Na} /[(\mathrm{Ca}+\mathrm{Mg}) / 2]^{1 / 2}$ soluble cation concentrations expressed in meq. $/ \mathrm{L}$ for calculation.

'Each value represents the means of 30 samples.

Table 2. Precipitation and free water evapontion data collected at Knife River Mine near Gascoyne, North Dakota.

\begin{tabular}{|c|c|c|c|c|c|c|c|}
\hline \multirow[b]{2}{*}{ Month } & \multicolumn{4}{|c|}{ Precipitation } & \multicolumn{3}{|c|}{ Evaporation } \\
\hline & 1977 & 1978 & 1979 & LTA' $^{\prime}$ & 1977 & 1978 & 1979 \\
\hline & & - & & - & 一- & $-\mathrm{mm}-$ & - - - \\
\hline June & 108 & 78 & 51 & 97 & 326 & 284 & 287 \\
\hline July & 41 & 85 & 77 & 56 & 351 & 314 & 276 \\
\hline August & 74 & 38 & 80 & 45 & 280 & 242 & 275 \\
\hline September & 133 & 67 & 31 & 35 & 162 & 208 & 234 \\
\hline $\begin{array}{l}\text { Growing season } \\
\text { Total }\end{array}$ & 356 & 268 & 239 & 233 & & & \\
\hline
\end{tabular}

'Long term average (30+ years) from U.S. Weather Bureau records, Bowman, ND., $22 \mathrm{~km} \mathrm{W.} \mathrm{of} \mathrm{mine.}$

Table 3. Temperature and wind speed data collected at Knife River Mine near Gascoyne, North Dakota.

\begin{tabular}{|c|c|c|c|c|c|c|c|}
\hline \multirow[b]{2}{*}{ Month } & \multicolumn{4}{|c|}{ Average Temperature } & \multicolumn{3}{|c|}{ Average Wind } \\
\hline & 1977 & 1978 & 1979 & LTA' $^{\prime}$ & 1977 & 1978 & 1979 \\
\hline & & $-\ldots$ & & - - - & -7 & $-\mathrm{m} \mathrm{s}^{-1}$ & \\
\hline June & 19.7 & 17.4 & 19.3 & 16.6 & 3.4 & 2.8 & 3.6 \\
\hline July & 21.6 & 20.9 & 20.6 & 21.1 & 3.6 & 2.4 & 2.5 \\
\hline August & 17.8 & 20.7 & 19.3 & 20.5 & 2.8 & 2.1 & 2.7 \\
\hline September & 15.1 & 16.1 & 17.4 & 14.0 & 3.3 & 2.4 & 2.7 \\
\hline
\end{tabular}

'Long term average (30+ years) from U.S. Weather Bureau records, Bowman, ND., $22 \mathrm{~km}$ W. of mine.

Table 4. Quality parameters of water used for irrigation.

\begin{tabular}{|c|c|c|c|c|c|c|c|}
\hline \multirow[b]{2}{*}{ Water } & \multirow[b]{2}{*}{ Year } & \multirow[b]{2}{*}{$\mathbf{E C}^{\mathbf{l}}$} & \multirow[b]{2}{*}{ Tconc. $^{2}$} & \multirow[b]{2}{*}{$\mathbf{S A R}^{3}$} & \multicolumn{3}{|c|}{ Hazard 4} \\
\hline & & & & & Class & Salinity & Sodicity \\
\hline Medium Qualitys & 1977 & $\begin{array}{c}\mathrm{dS} \mathrm{m} \mathrm{m}^{-1} \\
1.0\end{array}$ & $\underset{14.5}{\operatorname{meq} . / 1}$ & 6.5 & C3-S2 & High Medium & \\
\hline Low Quality & $\begin{array}{l}1977 \\
1978\end{array}$ & $\begin{array}{l}3.2 \\
3.8\end{array}$ & $\begin{array}{l}36.4 \\
43.8\end{array}$ & $\begin{array}{l}11.6 \\
18.2\end{array}$ & $\begin{array}{l}\text { C4-S3 } \\
\text { C4-S4 }\end{array}$ & $\begin{array}{l}\text { Very High } \\
\text { Very High }\end{array}$ & $\begin{array}{l}\text { High } \\
\text { Very High }\end{array}$ \\
\hline
\end{tabular}

'Salinity as measured by electrical conductivity (EC).

2Tconc. = total concentration

${ }^{2}$ Sodium adsoprtion ratio $=\mathrm{SAR}=\mathrm{Na} /[(\mathrm{Ca}+\mathrm{Mg}) / 2]^{1 / 2} ;$ concentration of cations used in calculation are expressed in meq. $/ \mathrm{L}$

4 (U.S. Salinity Laboratory Staff 1954) p. 80.

s"Medium" and "low" are relative terms arbitrarily chosen and do not imply water classification. 
quality water was ground water intercepted by mining and pumped from the pit. Samples of both waters were analyzed for EC, calcium, magnesium, and sodium concentrations and SAR was calculated (Table 4).

from the pit. Samples of both waters were analyzed for EC, calcium, magnesium, and sodium concentrations and SAR was calculated (Table 4).

Ten water treatments were evaluated. These treatments are listed in Table 5 along with actual amounts of water applied during the study. Besides the precipitation control plots, there were 3 levels of total water applied (precipitation plus irrigation) per season for each water quality (medium and low). Level 1 received $193 \mathrm{~mm}$ of water during the season (about $75 \%$ expected average precipitation). Level 2 approximated mean free water evaporation of 628 $\mathrm{mm}$ during the 3-month season. Level 3 was arbitrarily set at 915 $\mathrm{mm}$ during the season.

Water treatments were randomly assigned to each of the 10 plots in each block. Water was applied to each plot by dripping through a 120 by $180 \mathrm{~cm}$ galvanized pan with $0.8 \mathrm{~mm}$ holes in the bottom, at the rate of about $25 \mathrm{~mm}$ per hour. Each plot had a soil border (76 $\mathrm{mm}$ high) around it to prevent runon and runoff. Irrigation to supplement natural precipitation was applied during the months of July, August, and September of 1977 and 1978. Medium quality water was applied for one year and low quality water (worst case) was applied for 2 years. The total water required per season was divided by the number of weeks irrigation was applied to obtain weekly application amounts. Any precipitation received was subtracted from the weekly application amounts. If water was needed above precipitation, it was applied to the appropriate plot. Because precipitation occasionally exceeded the weekly rate, actual quantities of water received (Table 5) were slightly higher than planned. No irrigation was applied during the 1979 growing season.

Soil water in each plot was measured periodically with a neutron meter by $300-\mathrm{mm}$ increments to a depth of $2,400 \mathrm{~mm}$. Available soil water (total soil water minus $1.5 \mathrm{MPa}$ soil water) is shown at the beginning of the study in June of 1977 and in May of both 1978 and 1979 in Table 6.

Vegetation yield, used as an indirect measure of establishment, was measured in late summer each year by clipping at ground level, two $929-\mathrm{cm}^{2}$ areas from each plot. The vegetation was separated
Table 6. Available soll water at the start of season.

\begin{tabular}{|c|c|c|c|c|}
\hline \multirow{2}{*}{\multicolumn{2}{|c|}{ Water Treatments }} & \multicolumn{3}{|c|}{ Available Soil Water ${ }^{1}$} \\
\hline & & Jun 77 & May 78 & May 79 \\
\hline & \multirow{3}{*}{$\begin{array}{l}\text { Natural Pptn.2 } \\
\text { Pptn. + MOW3 }\end{array}$} & \multicolumn{2}{|c|}{$\mathrm{mm} \mathrm{H}_{2} \mathrm{O} / 910 \mathrm{~mm}$} & Soil/Spoil \\
\hline & & 1 & 48 & 4 \\
\hline & & & & \\
\hline & $193 \mathrm{~mm} ; 1 \mathrm{yr}$. & 4 & 11 & 11 \\
\hline 3. & Pptn. + MQW & & & \\
\hline & $628 \mathrm{~mm} ; 1 \mathrm{yr}$. & 8 & 69 & 14 \\
\hline 4. & Pptn. + MQW & & & \\
\hline & 915 mm; 1 yr. & 8 & 100 & 34 \\
\hline & Pptn. + LQW4 & & & \\
\hline & 193 mm; 1 yr. & 4 & 18 & 11 \\
\hline & Pptn + LQW & & & \\
\hline & $628 \mathrm{~mm} ; 1 \mathrm{yr}$. & $\mathbf{0}$ & 74 & 14 \\
\hline & Pptn. + LQW & & & \\
\hline & $915 \mathrm{~mm} ; 1 \mathrm{yr}$. & 0 & 104 & 9 \\
\hline & Pptn. + LQW & & & \\
\hline & $193 \mathrm{~mm} ; 2 \mathrm{yr}$. & $\mathbf{0}$ & 24 & 3 \\
\hline 9. & Pptn. + LQW & & & \\
\hline & $628 \mathrm{~mm} ; 2 \mathrm{yr}$. & 4 & 75 & 21 \\
\hline 10. & Pptn. + LQW & & & \\
\hline & 915 mm; 2 yr. & 1 & 79 & 44 \\
\hline
\end{tabular}

${ }^{1}$ Available soil water $=$ Total soil water minus $1.5 \mathrm{MPa}$ soil water.

${ }^{2}$ Pptn. = Precipitation

${ }^{3} \mathrm{MQW}=$ Medium Quality Water

LQW = Low Quality Water

into seeded forage species and weeds, oven-dried at $60^{\circ} \mathrm{C}$ for $48 \mathrm{~h}$, and weighed.

Data were analyzed as a randomized complete block analysis of variance. The significance of differences between means for vegetation yield was determined by a Fisher's protected least significant difference (LSD) test at $P \leq .05$ (Steel and Torrie 1980). The relationships of total yield of seeded and weed species to total water applied by irrigation were evaluated by correlation analysis.

Mean changes in soil/spoil salinity and sodicity were calculated by subtracting the ending (Fall 1979) EC and SAR from the baseline (Spring 1977) EC and SAR level by each soil depth. Comparisons of the quantity of change under the various water

Table 5. Precipitation and water added by irrigation to 10 water treatments during the 3 year period.

\begin{tabular}{|c|c|c|c|c|c|c|c|c|c|}
\hline \multirow{3}{*}{\multicolumn{2}{|c|}{ Water Treatments }} & \multicolumn{8}{|c|}{ Precipitation, Water Added by Irrigation (Jul - Sep) } \\
\hline & & \multicolumn{3}{|c|}{1977} & \multicolumn{3}{|c|}{1978} & \multirow{2}{*}{$\begin{array}{l}\text { Total Added } \\
\text { by Irrigation } \\
1977-78\end{array}$} & \multirow{2}{*}{$\frac{1979}{\text { Precip. }}$} \\
\hline & & Precip. & Irr. & Total & Precip. & Irr. & Total & & \\
\hline $\begin{array}{l}1 . \\
2 .\end{array}$ & $\begin{array}{l}\text { Natural Pptn.1 } \\
\text { Pptn. + MQW22 }\end{array}$ & 248 & $\mathbf{0}$ & 248 & 190 & 0 & 190 & 0 & 188 \\
\hline \multirow{2}{*}{$\begin{array}{l}3 . \\
4 .\end{array}$} & $\begin{array}{l}193 \mathrm{~mm} \text {; } 1 \text { yr. } \\
\text { Pptn. + MOW }\end{array}$ & 248 & 47 & 295 & 190 & 0 & 190 & 47 & 188 \\
\hline & $\begin{array}{l}628 \mathrm{~mm} ; 1 \text { yr. } \\
\text { Pptn. + MQW }\end{array}$ & 248 & 382 & 630 & 190 & 0 & 190 & 382 & 188 \\
\hline 5. & $\begin{array}{l}915 \mathrm{~mm} ; 1 \text { yr. } \\
\text { Pptn. + LQW33 }\end{array}$ & 248 & 697 & 945 & 190 & 0 & 190 & 697 & 188 \\
\hline 6. & $\begin{array}{l}193 \text { mm; } 1 \text { yr. } \\
\text { Pptn. + LQW }\end{array}$ & 248 & 47 & 295 & 190 & $\mathbf{0}$ & 190 & 47 & 188 \\
\hline \multirow{2}{*}{$\begin{array}{l}7 . \\
8 .\end{array}$} & $\begin{array}{l}628 \mathrm{~mm} ; 1 \mathrm{yr} . \\
\text { Pptn. + LQW }\end{array}$ & 248 & 382 & 630 & 190 & 0 & 190 & 382 & 188 \\
\hline & $\begin{array}{l}915 \mathrm{~mm} \text {; l yr. } \\
\text { Pptn. + LQW }\end{array}$ & 248 & 697 & 945 & 190 & $\mathbf{0}$ & 190 & 697 & 188 \\
\hline & $\begin{array}{l}193 \mathrm{~mm} ; 2 \mathrm{yr} \\
\text { Pptn. + LQW }\end{array}$ & 248 & 47 & 295 & 190 & 34 & 224 & 81 & 188 \\
\hline & $\begin{array}{l}628 \mathrm{~mm} ; 2 \mathrm{yr} . \\
\text { Pptn. + LQW }\end{array}$ & 248 & 382 & 630 & 190 & 391 & 581 & 773 & 188 \\
\hline & $915 \mathrm{~mm} ; 2$ yr. & 248 & 697 & 945 & 190 & 728 & 918 & 1425 & 188 \\
\hline
\end{tabular}

${ }_{1}^{1}$ Pptn. $=$ Precipitation

2MQW = Medium Quality Water

${ }^{3}$ LQW $=$ Low Quality Water 
Table 7. Yield of seeded forage species.

\begin{tabular}{|c|c|c|c|c|}
\hline \multirow[b]{3}{*}{ Water Treatment } & \multicolumn{4}{|c|}{ Seeded Forage Yield $\left(\mathrm{g} \mathrm{m}^{-2}\right)$} \\
\hline & \multicolumn{3}{|c|}{ Years } & \multirow{2}{*}{$\frac{\text { Total }}{1977-79}$} \\
\hline & 1977 & 1978 & 1979 & \\
\hline & \multicolumn{3}{|c|}{ LSD .05 Years $=85$} & \\
\hline $\begin{array}{ll}\text { 1. } & \text { Pptn. } \\
\text { 2. } & \text { Pptn. + MOW }\end{array}$ & 4 & 302 & 51 & 357 \\
\hline $\begin{array}{l}193 \mathrm{~mm} ; 1 \mathrm{yr} . \\
\text { 3. Pptn. + MQW }\end{array}$ & 7 & 268 & 59 & 334 \\
\hline $\begin{array}{l}628 \mathrm{~mm} ; 1 \mathrm{yr} . \\
\text { 4. Pptn. + MQW }\end{array}$ & 130 & 425 & 65 & 620 \\
\hline $\begin{array}{l}915 \mathrm{~mm} ; 1 \mathrm{yr} . \\
\text { 5. Pptn. + LQW }\end{array}$ & 192 & 495 & 96 & 783 \\
\hline $\begin{array}{l}193 \mathrm{~mm} ; 1 \text { yr. } \\
\text { 6. Pptn. + LQW }\end{array}$ & 12 & 373 & 69 & 454 \\
\hline $\begin{array}{l}628 \mathrm{~mm} ; 1 \mathrm{yr} . \\
\text { 7. Pptn. + LQW }\end{array}$ & 125 & 522 & 127 & 774 \\
\hline $\begin{array}{l}915 \mathrm{~mm} ; 1 \mathrm{yr} . \\
\text { 8. Pptn. + LQW }\end{array}$ & 199 & 557 & 108 & 864 \\
\hline $\begin{array}{l}193 \mathrm{~mm} ; 2 \mathrm{yr} . \\
\text { 9. Pptn. + LQW }\end{array}$ & 12 & 400 & 61 & 473 \\
\hline $\begin{array}{l}628 \mathrm{~mm} ; 2 \mathrm{yr} . \\
\text { 10. } \\
\text { Pptn. + LQW }\end{array}$ & 150 & 663 & 163 & 976 \\
\hline $\begin{array}{l}915 \mathrm{~mm} ; 2 \mathrm{yr} \\
\text { LSD .05 }\end{array}$ & $\begin{array}{l}136 \\
101\end{array}$ & $\begin{array}{l}701 \\
246\end{array}$ & $\begin{array}{r}212 \\
66\end{array}$ & $\begin{array}{r}1049 \\
321\end{array}$ \\
\hline
\end{tabular}

'Pptn. = Precipitation

${ }^{2} \mathrm{MQW}=$ Medium Quality Water

${ }^{3}$ LQW = Low Quality Water

treatments was accomplished by a Fisher's protected LSD test at $P \leq .05$ (Steel and Torrie 1980).

\section{Results and Discussion}

\section{Vegetation Yield}

In 1977 , forage yields were greater than the control on plots that received 382 or $697 \mathrm{~mm}$ of irrigation (water treatments 3, 6,9 and 4, 7,10 , respectively, Table 7 ). No significant ( $P \leq .05$ ) effect of water quality was observed (treatments 3 vs 6 and 9 , and 4 vs 7 and 10 ). Vegetation yield was greatest for the year 1978. In 1978, yield was greater on plots that received $697 \mathrm{~mm}$ (treatment 7) of low quality water during 1977 and 391 and $728 \mathrm{~mm}$ (treatments 9 and 10) of low quality water during 1978 compared to the control. In 1979, the growing season when no irrigation was applied, forage yield was greater than the control on plots that received 773 and $1,425 \mathrm{~mm}$ of low quality irrigation water for 2 years (treatments 9 and 10 , respectively). Forage yield was also greater than the control in 1979 on plots that had received $382 \mathrm{~mm}$ (treatment 6) of low quality water during 1977.

In 1977 , stand composition, based on dry matter weight, consisted of $27 \%$ wheatgrasses, a trace of green needlegrass, $49 \%$ annual rye, $21 \%$ clover, and $3 \%$ weedy species. Composition changed in favor of the wheatgrasses (72\%) in 1978. Green needlegrass was still present in trace amounts, while annual rye, clover, and weedy species were present at compositions of 5,3 , and $20 \%$, respectively. By 1979, no green needlegrass was present in the stands. Wheatgrasses composed $59 \%$ of the stands, while weedy species composed $41 \%$. Kochia (Kochia scoparia L.) was the dominant weed, making up $97 \%$ of the weedy species composition.

Total forage yield for $1977-79$ was correlated with the 1977 and 1978 irrigation water applied. Yield differences between plots receiving the same quantity of medium and low quality water for one season were not significant ( $P \leq .05$, Table 7$)$. Figure 1 shows the relationship of total forage yield to total irrigation water added ( $r=0.93$, significant @P $P .01$ ). This is important because the more water added resulted in better stand establishment as shown by increased production of seeded forage species.

The relationship of 1979 forage and weed yields with total water added by irrigation in 1977 and 1978 is shown in Figure 2. Both the

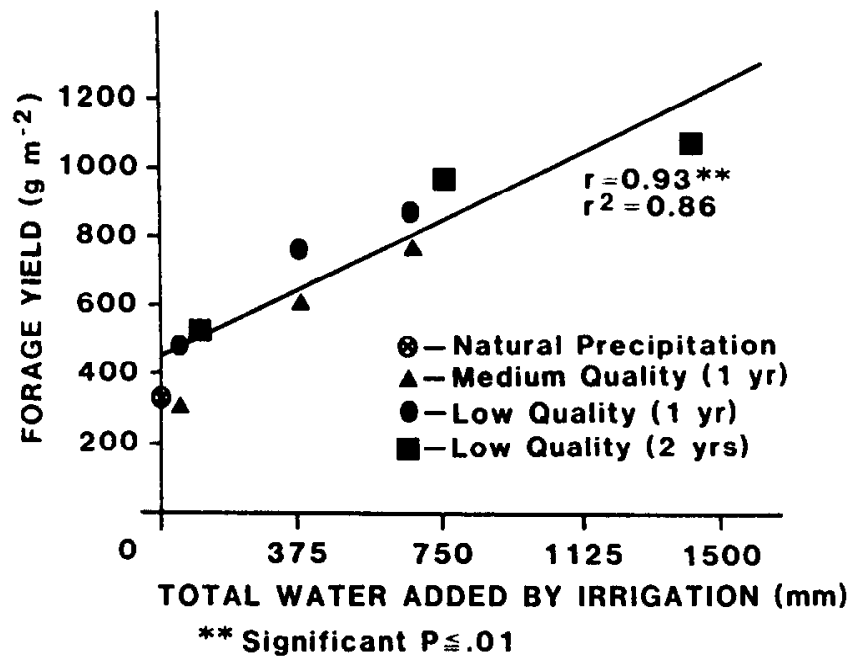

Fig. 1. Relationship of total seeded forage yield (1977-79) to total water added by irrigation during 1977 and 1978.

seeded forage species and weed yields were significantly related to total water added by irrigation $(r=0.91$ and $r=0.77 @ P \leq .01$, respectively). The relationship was positive for the forage species and negative for the weeds. Therefore, during 1979, both forage and weed yields still reflected water added above natural precipitation during 1977 and 1978. Stands receiving added water increased in yield of forage species and had fewer weeds. These data further show that the seeded forage species established more competitive stands when supplied with irrigation water, regardless of water quality. The annual weedy species were unable to compete with these more vigorous perennial forage species and thus showed a decrease in dry matter with increased irrigation water.

\section{Soil/Spoil Changes}

Water penetration on the precipitation only treatment was observed to a depth of $1,800 \mathrm{~mm}$ while on irrigated plots soil water movement was observed to a depth of $2,100 \mathrm{~mm}$. This indicates that the soil/spoil profile was moderately permeable. Soil/spoil changes in salinity and sodicity from baseline conditions (Table 1,

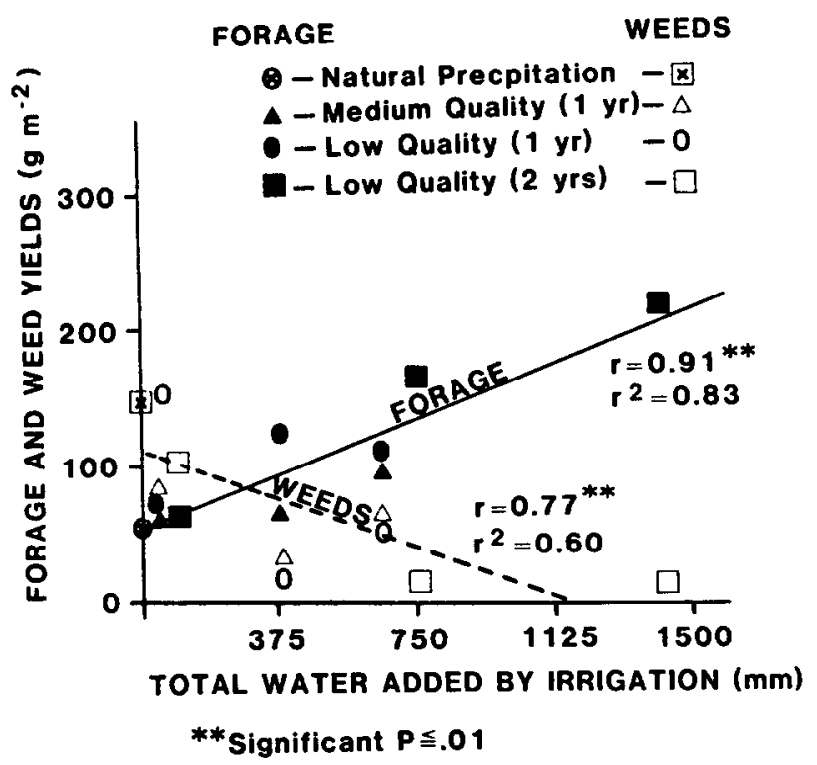

Fig. 2. Relationship of 1979 forage and weed yields with total water added by irrigation during 1977 and 1978. 


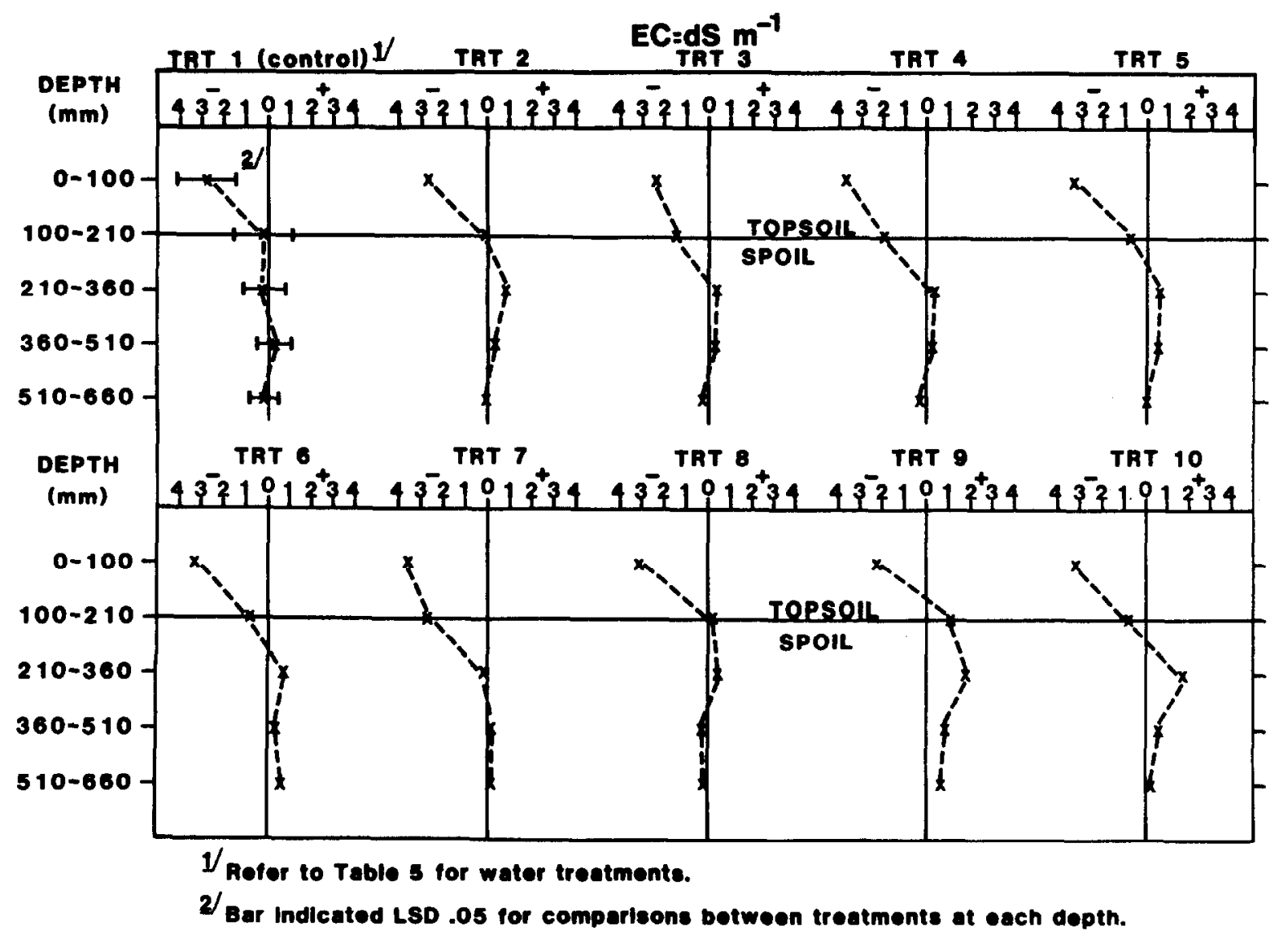

Fig. 3. Changes in salinity (EC) level of soil/spoil profiles from beginning of study (Spring 1977) 10 end of study (Fall 1979).

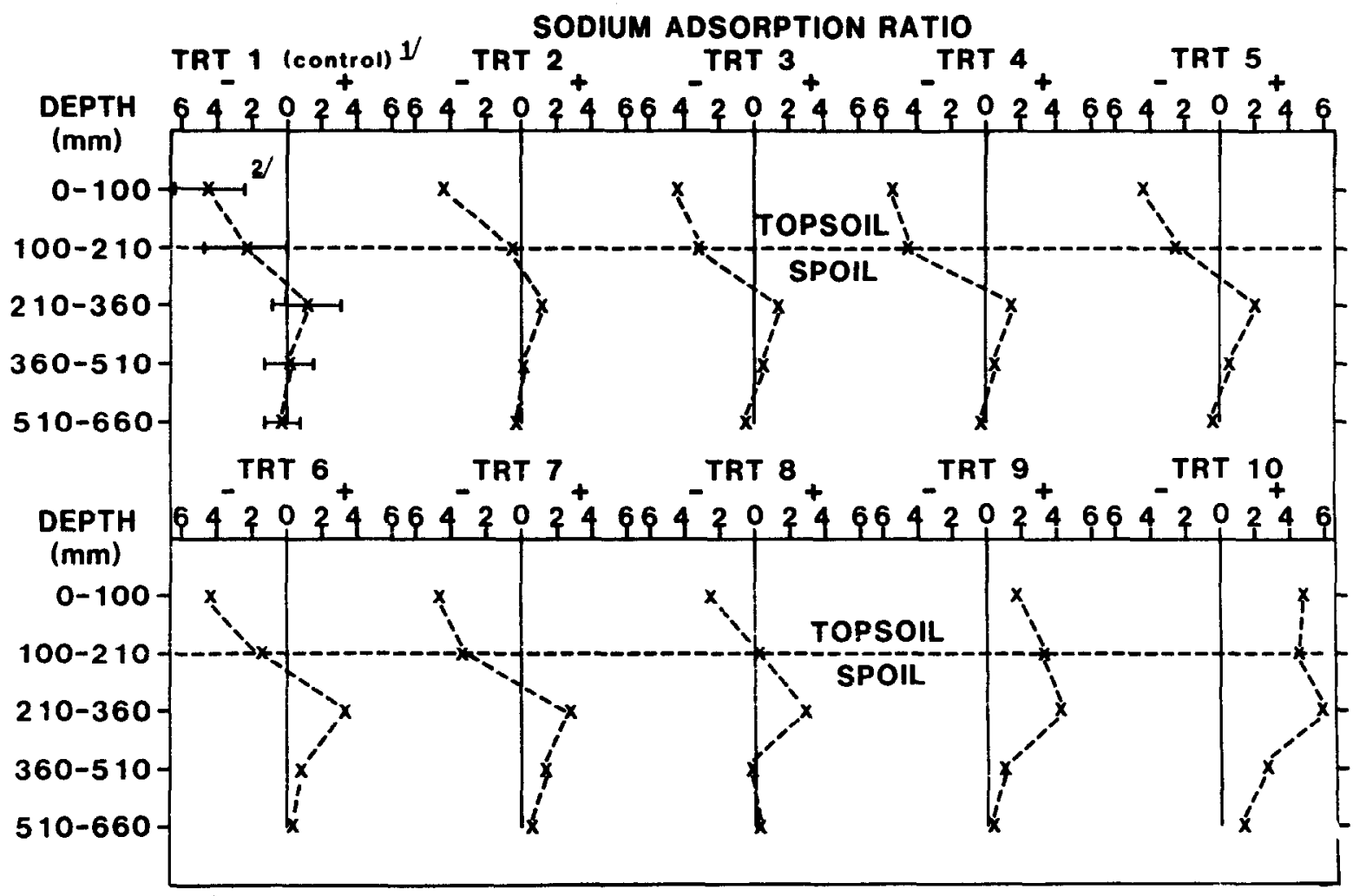

$1 /$ Refer to Table 5 for water treatments.

2/Bar indicated LSD .05 for comparisons between treatments at each depth.

Fig. 4. Change in sodium adsorption ratio (SAR) of the soil/spoil profile from beginning of study (Spring 1977) to end of study (Fall 1979). 
Spring 1977) to the end of the study (Fall 1979) were used to assess the salinity and sodicity effect of different qualities and quantities of irrigation water. Significant changes $(P \leq .05)$ in salinity and sodicity during the study were observed only to a depth of $660 \mathrm{~mm}$. Compared to the control treatment, significant $(P \leq .05)$ decreases in EC were observed at the 100 to $210 \mathrm{~mm}$ depth in plots receiving $697 \mathrm{~mm}$ (treatment 4 and 7) of either medium or low quality water added during 1977, but a significant ( $P \leq .05$ ) increase in EC was observed at the 510 to $660 \mathrm{~mm}$ depth when $382 \mathrm{~mm}$ low quality water (treatment 6) was added during 1977 (Fig. 3). With a total of $773 \mathrm{~mm}$ low quality water (treatment 9) added in 1977 and 1978, a significant $(P \leq .05)$ increase in EC over the control plots was observed at the 210 to 360 and 510 to $660 \mathrm{~mm}$ depths (Fig. 3). When $1,425 \mathrm{~mm}$ low quality water (treatment 10 ) were added in 1977 and 1978 , a significant $(P \leq .05)$ increase in EC was observed at the 210 to $360 \mathrm{~mm}$ depth (Fig. 3).

Compared to the control, SAR increased at the 210 to $360 \mathrm{~mm}$ depth from $382 \mathrm{~mm}$ low quality water (treatment 6) added in 1977 (Fig. 4). Increases in SAR were observed when low quality water was applied for 2 years. The plots that received $81 \mathrm{~mm}$ (treatment 8) showed decreased SAR at the 0 to $100 \mathrm{~mm}$ depth, and plots receiving $773 \mathrm{~mm}$ (treatment 9) showed increased SAR in the 0 to $360 \mathrm{~mm}$ soil/spoil zone (Fig. 4). The $1,425 \mathrm{~mm}$ low quality water (treatment 10) added in 1977 and 1978 increased SAR throughout the whole 0 to $660 \mathrm{~mm}$ soil/spoil profile (Fig. 4).

The findings are consistent with those reported by Zartman et al. (1980) and Jury et al. (1980) from the use of blowdown water for irrigation. Changes in EC in our study are considered slight. The SAR increase was more pronounced than salinity increase and appeared to be primarily related to the low quality water applied in 1978.

\section{Conclusion}

Irrigation with low quality water improved perennial plant establishment as measured by production. In the growing season after irrigation was terminated, seeded forage yield was increased and weed dry matter decreased within stands established with supplemental irrigation compared to the stand established with precipitation only. Water quality had no effect on forage yield.
When low quality water was used for 1 year to supplement precipitation, changes in salinity and sodicity, evaluated by EC and SAR, were minor. When a total of at least $773 \mathrm{~mm}$ of low quality water was added over 2 growing seasons, EC increases were observed at the 210 to $360 \mathrm{~mm}$ depth and SAR increases at the 0 to $360 \mathrm{~mm}$ zone. Sodicity increased in the zone of 0 to $660 \mathrm{~mm}$ when $1,425 \mathrm{~mm}$ of low quality water were added over 2 years.

Results from this study indicate that, in well-drained spoils, low quality irrigation can be used to supplement precipitation for 1 to 2 seasons to establish forage stands. This appears to be an acceptable revegetation technique for disturbed areas of medium textures with moderately permeable soil profiles.

\section{Literature Cited}

Croft, M.G. 1974. Ground-water basic data for Adams and Bowman Counties, North Dakota. Bull 65-Part Il. U.S. Geol. Surv. Bismarck, N.Dak..

Epstein, E., and J.D. Norlyn. 1977. Seawater-based crop production: a feasibility study. Science 197:249-251.

Gilley, J.E., G.W. Gee, and A. Bauer. 1976. Water quality of impoundments on surface-mined sites. North Dakota Agr. Exp. Sta. Res. 34:37-39.

Jury, W.A., H.J. Vaux, Jr., and L.H. Stolzy. 1980. Reuse of power plant cooling water for irrigation. Water Resour. Bull. 16:830-836.

Ries, R.E. and A.D. Day. 1978. Use of irrigation in reclamation in dry regions. p. 505-520. F.W. Schaller and Paul Sutton (ed.). In: Reclamation of Drastically Disturbed Lands. Amer. Soc. Agron., Madison, Wis.

Ries, R.E. 1980. Supplemental water for the establishment of perennial vegetation on strip-mined lands. North Dakota Agr. Exp. Sta. Res. 37:21-23.

Sandoval, F.M. and J.F. Power. 1977. Laboratory methods recommended for chemical analysis of mined-land spoils and overburden in western United States. Agr. Handb. 525, USDA. Washington, D.C.

Steel, R.G.D. and J.H. Torrie. 1980. Principles and procedures of statistics. McGraw-Hill Book Co. New York.

Thomas, J.R., F.G. Salinas, and G.F. Oerther. 1981. Use of saline water for supplemental irrigation of sugarcane. Agron. J. 73:1011-1017.

U.S. Salinity Laboratory Staff. 1954. Diagnosis and improvement of saline and alkali soils. Agr. Handb. 60, USDA, Washington, D.C.

Zartman, R.E., T.D. Miller, J.R. Goodin, and M. Gichara. 1980. Effects of water quality on forage production. J. Environ. Qual. 9:187-190. 